$\begin{gathered}\text { Науковий вісник НлтУ України } \\ \text { Scientific Bulletin of UNFU } \\ \text { http://nv.nltu.edu.ua }\end{gathered}$
$\begin{array}{r}\text { https://doi.org/10.15421/40290722 } \\ \text { Article received 21.06.2019 p. } \\ \text { Article accepted 26.09.2019 p. } \\ \text { Удк 58.036.5:582.746.26(477.[4+7]) }\end{array}$

В. П. Шлапак, В. В. Мамчур, С. А. Коваль, Г. П. Іщук, С. С. Курка

Уманський національний університет садівництва, м. Умань, Украӥна

\title{
СЕЗОННI РИТМИ РОСТУ I РОЗВИТКУ AILANTHUS ALTISSIMA MILL. В УМОВАХ ПРАВОБЕРЕЖНОГО ЛІСОСТЕПУ І СТЕПУ УКРАЇНИ
}

\begin{abstract}
Досліджено сезонні ритми розвитку та росту айланта найвищого (Aailanthus altissima Mill.) в умовах Правобережного Лісостепу і Степу України. Встановлено терміни проходження різних фаз розвитку A. altissima в умовах Правобережного Лісостепу і Степу України. Доведено, що за сумарною сонячною радіацією як показником, від якого залежить ріст і розвиток рослин, Правобережний Лісостеп і Степ України близькі до більшості районів природного поширення A. altissima у Південно-Східній Азії. Обгрунтовано, що вегетаційний період у Правобережному Лісостепу України триває 190-200 діб, і 210220 діб у Степу України, а суми активних температур (понад $+10{ }^{\circ} \mathrm{C}$ ) у Правобережному Лісостепу становлять $2800-$ $3000{ }^{\circ} \mathrm{C}$, а в Південному Степу в умовах природного ареалу $-3300-3500{ }^{\circ} \mathrm{C}$. Період вегетації A. altissima в середньому становить 190-200 діб у Правобережному Лісостепу України і 210-220 діб у Степу України. Вегетаційний період у рослин A. altissima починається у разі настання середньодобової температури $+7,8-10,5^{\circ} \mathrm{C} 3$ фаз бубнявіння та розпукування бруньок. Основні фази сезонного розвитку рослин A. altissima у Степу настають на декілька діб раніше, ніж у Лісостепу, що пояснюють швидшим зростанням суми температур у степовій зоні. Встановлено, що на механізми, які регулюють ростові процеси, безпосередньо впливає температура повітря. Досліджено основні фази сезонного розвитку виду A. altissima інтродукованого в Правобережному Лісостепу і Степу України. Наведено результати дослідження основних фаз росту й розвитку рослин виду A. altissima, які зростають у Національному дендрологічному парку "Софіївка" НАН України, Уманському НУС, у зелених насадженнях Умані та Уманського району, Одеси, Миколаєва. Виявлено, що фаза бутонізації A. altissima розпочинається за суми ефективних температур $+249^{\circ} \mathrm{C}$, що припадає на третю декаду квітня в Лісостепу та на другу - у Степу. Проміжок часу від початку бутонізації до початку квітування становить у середньому 24 доби. Початок квітування спостерігаємо за суми ефективних температур $+543{ }^{\circ} \mathrm{C}$. Після закінчення квітування від моменту запліднення до початку достигання насінини відбувається її розвиток. Дозрівання плодів A. altissima спостерігаємо наприкінці липня, що триває до кінця жовтня - першої декади листопада. Порівнюючи проходження всіх основних фаз сезонного розвитку рослин A. altissima в Правобережному Лісостепу та Степу України, можна зробити висновок, що в Степу вони настають на декілька діб раніше, ніж у Лісостепу. Це пояснено особливостями зростання суми температур у Степовій зоні.
\end{abstract}

Ключові слова: Aailanthus altissima Mill.; ріст; розвиток; вегетаційний період; температура.

Вступ. Для успішного впровадження рослин-інтродуцентів у культуру в нових умовах важливо визначити зміни в ритмі життєвих процесів. Одними з доступних і ефективних методів дослідження інтродукованих рослин $є$ методи фенологічних спостережень. Вони дають змогу встановити терміни проходження різних фаз розвитку, оцінити стійкість, продуктивність, декоративність рослин (Yurkevich, Golod \& Yaroshevich, 1980).

Мета дослідження - вивчити сезонні ритми росту і розвитку Ailanthus altissima Mill. в умовах Правобережного Лісостепу і Степу України.

Об'єкти та методика дослідження. Для аналізу основних фаз росту і розвитку Ailanthus altissima Mill. впродовж 2015-2017 pp. проводили спостереження за його фенологічними ритмами росту і розвитку в зеле- них насадженнях Умані, Уманського району, дендрологічного парку "Софіївка" НАН України та Одеси.

Фенологічні спостереження за A. altissima проводили впродовж 2014-2017 рр. за методикою R. P. Alexeyev (1998) та "Методикой фенологических наблюдений в ботанических садах CCCP (1975)" (GSS of the Academy of Sciences of the USSR.), за загальноприйнятими методиками фенологічних спостережень (Zaitsev, 1981; Plotnikova, 1973; Nesterov \& Tikhonov, 1972) тощо.

Результати дослідження. Одночасно 3 фенологічними спостереженнями фіксували метеорологічні дані в районі дослідження. Показником кількості тепла, яке необхідне для вегетації, $є$ сума ефективних температур, що визначається підрахунком суми середньодобових температур (Zaitsev, 1981; Plotnikova, 1973).

\section{Інформація про авторів:}

Шлапак Володимир Петрович, д-р с.-г. наук, професор, завідувач кафедри лісового господарства. Email: shlapakwp@gmail.com

Мамчур Валентина Василівна, канд. с.-г. наук, викладач, кафедра лісового господарства. Email: mamcurvalentina@gmail.com

Коваль Сергій Анатолійович, канд. с.-г. наук, доцент, кафедра лісового господарства. Email: sergiykoval24@gmail.com

Іщук Галина Петрівна, канд. с.-г. наук, доцент, кафедра лісового господарства. Email: sobaka.kot2011@gmail.com

Курка Світлана Сергіївна, канд. біол. наук, доцент, кафедра лісового господарства. Email: svetlana9075@ukr.net

Цитування за ДСтУ: Шлапак В. П., Мамчур В. В., Коваль С. А., Іщук Г. П., Курка С. С. Сезонні ритми росту і розвитку Ailanthus altissima Mill. в умовах Правобережного Лісостепу і Степу України. Науковий вісник НЛТУ України. 2019, т. 29, № 7. С. 112-114.

Citation APA: Shlapak, V. P., Mamchur, V. V., Koval, S. A., Ishchuk, G. P., \& Kurka, S. S. (2019). Seasonal Rhythms of Growth and Development of Ailanthus altissima Mill. in the Conditions of Right-Bank Forest-Steppe and Steppe of Ukraine. Scientific Bulletin of UNFU, 29(7), 112-114. https://doi.org/10.15421/40290722 
Під час досліджень визначали суму ефективних температур вище $+10^{\circ} \mathrm{C}$, яка потрібна для початку окремих фаз вегетації A. altissima (табл. 1).

Табл. 1. Суми ефективних температур (вище $+10{ }^{\circ} \mathrm{C}$ ) на початок основних фенологічних фаз розвитку

А. altissima в Умані

\begin{tabular}{|c|c|c|c|}
\hline Фаза розвитку & $\begin{array}{c}\text { Рік } \\
\text { дослідження }\end{array}$ & Дата & $\sum_{t},{ }^{\circ} \mathrm{C}$ \\
\hline \multicolumn{4}{|c|}{ Фази розвитку вегетативних органів } \\
\hline \multirow{3}{*}{$\begin{array}{c}\text { Початок лінійного } \\
\text { розвитку пагонів }\end{array}$} & 2015 & $7.04^{ \pm 3}$ & 22,6 \\
\hline & 2016 & $11.04^{ \pm 4}$ & 45,9 \\
\hline & 2017 & $8.04^{ \pm 3}$ & 35,5 \\
\hline \multirow{3}{*}{$\begin{array}{c}\text { Початок } \\
\text { облиствлення }\end{array}$} & 2015 & $12.05^{ \pm 4}$ & 275,5 \\
\hline & 2016 & $20.04^{ \pm 2}$ & 186,4 \\
\hline & 2017 & $21.04^{ \pm 4}$ & 298,3 \\
\hline \multirow{3}{*}{$\begin{array}{c}\text { Завершення лінійно- } \\
\text { го росту пагонів }\end{array}$} & 2015 & $22.09^{ \pm 4}$ & 2862,0 \\
\hline & 2016 & $24.09^{ \pm 2}$ & 2815,5 \\
\hline & 2017 & $25.04^{ \pm 3}$ & 3161,5 \\
\hline \multirow{3}{*}{ Опадання листків } & 2015 & $28.10^{ \pm 3}$ & 3063,1 \\
\hline & 2016 & $20.10^{ \pm 4}$ & 3396,5 \\
\hline & 2017 & $17.10^{ \pm 3}$ & 3009,7 \\
\hline \multicolumn{4}{|c|}{ Фази розвитку генеративних органів } \\
\hline \multirow{3}{*}{ Початок квітування } & 2015 & $6.06^{ \pm 4}$ & 281,7 \\
\hline & 2016 & $5.06^{ \pm 4}$ & 540,0 \\
\hline & 2017 & $10.06^{ \pm 2}$ & 307,2 \\
\hline \multirow{3}{*}{$\begin{array}{l}\text { Закінчення } \\
\text { квітування }\end{array}$} & 2015 & $02.07^{ \pm 3}$ & 1309,5 \\
\hline & 2016 & $29.06^{ \pm 2}$ & 1186,8 \\
\hline & 2017 & $02.07^{ \pm 2}$ & 1203,2 \\
\hline \multirow{3}{*}{ Достигання насіння } & 2015 & $23.10^{ \pm 3}$ & 3064,2 \\
\hline & 2016 & $27.10^{ \pm 5}$ & 3384,2 \\
\hline & 2017 & $26.10^{ \pm 4}$ & 3034,5 \\
\hline
\end{tabular}

Порівнюючи проходження всіх основних фаз сезонного розвитку рослин A. altissima в Правобережному Лісостепу та Степу України, можна зробити висновок, що у Степу вони настають на декілька діб раніше, ніж у Лісостепу. Це пояснюємо особливостями зростання суми температур у Степовій зоні (табл. 2).

Табл. 2. Основні фази сезонного розвитку А. altissima інтродукованого у Правобережному Лісостепу та Степу України (середні дані)

\begin{tabular}{|c|c|c|c|}
\hline \multirow{2}{*}{ Фаза розвитку } & \multirow{2}{*}{ Рік } & Лісостеп & Степ \\
\hline & & \multicolumn{2}{|c|}{ дата початку розвитку } \\
\hline \multirow{3}{*}{$\begin{array}{l}\text { Набрякання } \\
\text { бруньок }\end{array}$} & 2015 & $7.03^{ \pm 2}$ & $4.03^{ \pm 3}$ \\
\hline & 2016 & $9.03^{ \pm 4}$ & $4.03^{ \pm 2}$ \\
\hline & 2017 & $8.03^{ \pm 3}$ & $5.03^{ \pm 4}$ \\
\hline \multirow{3}{*}{$\begin{array}{c}\text { Розпукування } \\
\text { бруньок }\end{array}$} & 2015 & $5.04^{ \pm 2}$ & $2.04^{ \pm 3}$ \\
\hline & 2016 & $8.04^{ \pm 5}$ & $4.04^{ \pm 1}$ \\
\hline & 2017 & $6.04^{ \pm 2}$ & $1.04^{ \pm 3}$ \\
\hline \multirow{3}{*}{$\begin{array}{c}\text { Початок лінійного } \\
\text { росту пагонів }\end{array}$} & 2015 & $7.04^{ \pm 3}$ & $3.04^{ \pm 5}$ \\
\hline & 2016 & $11.04^{ \pm 4}$ & $6.04^{ \pm 3}$ \\
\hline & 2017 & $8.04^{ \pm 3}$ & $3.04^{ \pm 2}$ \\
\hline \multirow{3}{*}{ Бутонізація } & 2015 & $25.05^{ \pm 5}$ & $19.05^{ \pm 1}$ \\
\hline & 2016 & $20.05^{ \pm 2}$ & $16.05^{ \pm 4}$ \\
\hline & 2017 & $23.05^{ \pm 2}$ & $20.05^{ \pm 2}$ \\
\hline \multirow{3}{*}{$\begin{array}{l}\text { Початок } \\
\text { квітування }\end{array}$} & 2015 & $6.06^{ \pm 4}$ & $4.06^{ \pm 2}$ \\
\hline & 2016 & $5.06^{ \pm 4}$ & $2.06^{ \pm 3}$ \\
\hline & 2017 & $10.06^{ \pm 2}$ & $5.06^{ \pm 3}$ \\
\hline \multirow{3}{*}{$\begin{array}{l}\text { Закінчення } \\
\text { квітування }\end{array}$} & 2015 & $28.06^{ \pm 2}$ & $24.06^{ \pm 3}$ \\
\hline & 2016 & $30.06^{ \pm 2}$ & $25.06^{ \pm 2}$ \\
\hline & 2017 & $6.07^{ \pm 3}$ & $3.07^{ \pm 2}$ \\
\hline \multirow{3}{*}{$\begin{array}{l}\text { Закінчення росту } \\
\text { лінійних пагонів }\end{array}$} & 2015 & $22.09^{ \pm 4}$ & $18.09^{ \pm 2}$ \\
\hline & 2016 & $24.09^{ \pm 2}$ & $19.09^{ \pm 3}$ \\
\hline & 2017 & $25.04^{ \pm 3}$ & $20.09^{ \pm 2}$ \\
\hline \multirow{3}{*}{$\begin{array}{c}\text { Початок } \\
\text { дозрівання плодів }\end{array}$} & 2015 & $20.07^{ \pm 4}$ & $16.07^{ \pm 3}$ \\
\hline & 2016 & $25.07^{ \pm 5}$ & $22.07^{ \pm 4}$ \\
\hline & 2017 & $23.07^{ \pm 2}$ & $17.07^{ \pm 4}$ \\
\hline \multirow{3}{*}{$\begin{array}{c}\text { Кінець дозрівання } \\
\text { плодів }\end{array}$} & 2015 & $23.10^{ \pm 3}$ & $16.10^{ \pm 1}$ \\
\hline & 2016 & $27.10^{ \pm 5}$ & $24.10^{ \pm 2}$ \\
\hline & 2017 & $26.10^{ \pm 4}$ & $22.10^{ \pm 2}$ \\
\hline \multirow{3}{*}{$\begin{array}{c}\text { Початок } \\
\text { листопаду }\end{array}$} & 2015 & $28.10^{ \pm 3}$ & $21.10^{ \pm 2}$ \\
\hline & 2016 & $20.10^{ \pm 4}$ & $15.10^{ \pm 5}$ \\
\hline & 2017 & $17.10^{ \pm 3}$ & $12.10^{ \pm 4}$ \\
\hline
\end{tabular}

\begin{tabular}{|c|c|c|c|}
\hline \multirow{2}{*}{ Кінець листопаду } & 2015 & $10.11^{ \pm 4}$ & $3.11^{ \pm 3}$ \\
& 2016 & $6.11^{ \pm 5}$ & $1.11^{ \pm 2}$ \\
& 2017 & $29.10^{ \pm 5}$ & $23.10^{ \pm 2}$ \\
\hline
\end{tabular}

Вегетаційний період у рослин A. altissima починається у разі настання середньодобової температури $+7,8-10,5^{\circ} \mathrm{C} 3$ фаз бубнявіння та розпукування бруньок. Далі їх супроводжує фаза лінійного росту пагонів, яка в Степу починається на початку першої декади квітня, а в Лісостепу - наприкінці першої - на початку другої декади. У середньому період росту пагонів триває 165 діб в Лісостепу та 174 доби в Степу.

Фаза бутонізації A. altissima починається за суми ефективних температур $+249{ }^{\circ} \mathrm{C}$, що припадає на третю декаду квітня в Лісостепу та на другу - в Степу. Проміжок часу від початку бутонізації до початку квітування становить у середньому 24 доби. Початок квітування спостерігаємо за суми ефективних температур $+543{ }^{\circ} \mathrm{C}$. Після закінчення квітування від моменту запліднення до початку іiї достигання відбувається розвиток насінини.

Дозрівання плодів A. altissima спостерігаємо наприкінці липня, що триває до кінця жовтня - першої декади листопада. Феноспектральний аналіз сезонного ритму розвитку генеративних і вегетативних органів $A$. altissima в умовах Правобережного Лісостепу і Степу України зображено на рисунку.

\section{Правобережний Лісостеп}

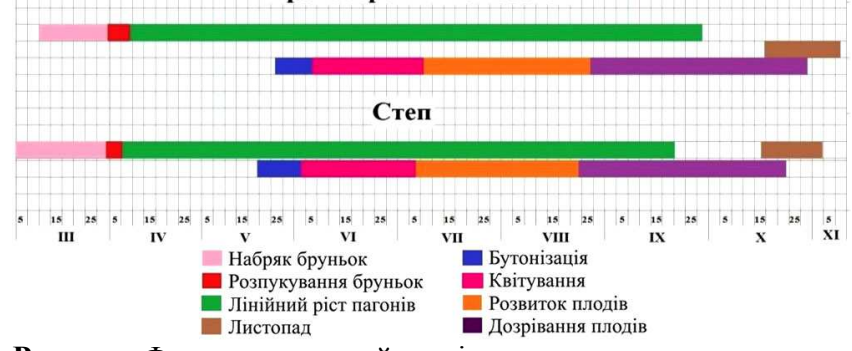

Рисунок. Феноспектральний аналіз сезонного ритму розвитку A. altissima в умовах Правобережного Лісостепу і Степу України

Період вегетації в середньому становить 215 діб. Зі зниженням температури припиняється ріст пагонів i настає листопад. Далі рослина входить у період спокою.

\section{Висновки:}

1. Період вегетації A. altissima в середньому становить 190-200 діб у Правобережному Лісостепу України і 210-220 діб у Степу України.

2. Вегетаційний період у рослин A. altissima починається у разі настання середньодобової температури $+7,8$ $10,5^{\circ} \mathrm{C}$ з фаз бубнявіння та розпукування бруньок.

3. Основні фази сезонного розвитку рослин A. altissima у Степу настають на декілька діб раніше, ніж у Лісостепу. Це пояснюємо швидшим зростанням суми температур у степовій зоні.

\section{Перелік використаних джерел}

Alexeyev, R. P. (1998). Method of analysis of plant development, taking into account meteorological factors. Michurinsk: Publishing House MGSHA, pp. 106-107. [In Ukrainian].

Nesterov, Ya. S., \& Tikhonov, V. A. (1972). A method for determining the terms of the period of rest of the fruit crops. Scientific achievements in practice, 2, 149-151. [In Ukrainian].

Observations. (1975). The method of phenological observations in the botanical gardens of the USSR. Moscow: GSS of the Academy of Sciences of the USSR, 27 p. [In Russian]. 
Plotnikova, L. S. (1973). The program of observations on the general and seasonal development of deciduous tree plants at their introduction. Experience in introducing tree plants. Moscow: Science, pp. 80-85. [In Russian].
Yurkevich, I. D., Golod, D. S., \& Yaroshevich, E. P. (1980). Phenological researches of woody and herbaceous plants. MN: Science and Technology, 88 p. [In Ukrainian].

Zaitsev, G. N. (1981). Phenology of woody plants. Moscow: Science, $120 \mathrm{p}$.

\section{SEASONAL RHYTHMS OF GROWTH AND DEVELOPMENT OF AILANTHUS ALTISSIMA MILL. IN THE CONDITIONS OF RIGHT-BANK FOREST-STEPPE AND STEPPE OF UKRAINE}

The seasonal rhythms of the development and growth of the Alanthus altissima Mill. in the conditions of the Right Bank Foreststeppe and Steppe of Ukraine are investigated. The periods of passage of different phases of development of A. altissima in the conditions of the Right-bank Forest-steppe and Steppe are established. It has been proved that the total solar radiation as an indicator on which growth and development of plants depends on, the Right Bank Forest-steppe and Steppe of Ukraine are close to most areas of natural distribution of A. altissima in Southeast Asia. It is substantiated that the vegetation period in the Right-bank Forest-steppe of Ukraine lasts 190-200 days, and 210-220 days in the Ukrainian Steppe, and the sum of active temperatures (more than $+10{ }^{\circ} \mathrm{C}$ ) in the Right-bank Forest-steppe makes 2800-3000 ${ }^{\circ} \mathrm{S}$, and in the Southern Steppe in conditions of the natural range $-3300-3500{ }^{\circ} \mathrm{S}$. The period of vegetation of A. altissima averages 190-200 days in the Right-bank Forest-steppe of Ukraine and 210-220 days in Ukrainian Steppe. The vegetative period in A. altissima plants begins at the onset of the average daily temperature of $+7.8-10.5^{\circ} \mathrm{C}$ from the phases of bubbling and budding. The main phases of seasonal development of $A$. altissima plants in Steppe occur several days earlier than in the Forest-steppe, which is explained by the rapid increase in the sum of temperatures in the steppe zone. It is established that the mechanisms regulating the growth processes are directly influenced by the air temperature. The main phases of seasonal development of A. altissima species, inoculated in the Right-bank Forest-steppe and Steppe, are investigated. The results of the study of the main phases of growth and development of plants of A. altissima species, which grow in the National Dendrological Park "Sofiyivka" of the National Academy of Sciences of Ukraine, Uman NPC, in green plantations of Uman and Uman District, Odesa, Mykolayiv, are presented. It has been found that the A. altissima budding phase begins at the sum of effective temperatures $+249^{\circ} \mathrm{C}$, which falls on the third part of April in the Forest-steppe and the second in Steppe. The interval from the beginning of budding to the beginning of flowering is an average of 24 days. The beginning of flowering is observed at the sum of effective temperatures $+543{ }^{\circ} \mathrm{C}$. The onset of seed reaches its development at the end of flowering from the moment of fertilization. The maturation of A. altissima fruit is observed at the end of July and lasts until the end of October - the first decade of November. Comparing the passage of all the main phases of the seasonal development of A. altissima plants in Right-bank Forest-steppe and Steppe of Ukraine, we can conclude that they occur in the Steppe several days earlier than in the Forest-steppe. This is due to the peculiarities of the increase in the sum of temperatures in the Steppe zone.

Keywords: Aailanthus altissima Mill.; growth; development; vegetation period; temperature. 